\title{
China and the Prospects of Denuclearization of North Korea
}

\author{
Fei-Ling Wang
}

\begin{abstract}
This article interprets and analyzes the role of China in and the prospects of denuclearization of North Korea. Driven by its ruling party's peculiar political interest of resisting, reducing, and replacing American power at the expense of its national interest of cooperating with the United States, Beijing has been alternatively facilitating (somewhat) and fettering (mostly) North Korean denuclearization to make the cause unavoidably long and arduous, if doable at all. The latest resumption of Beijing-Pyongyang ties, in reaction to the Trump-Kim summit, suggests that a fundamental change in Beijing's strategic stance on the North Korean nuclear issue has taken place, making genuinely enabling peaceful denuclearization of the DPRK rather difficult as it would require literally a political change-of-heart in Beijing.
\end{abstract}

Keywords Chinese foreign policy, Sino-U.S. relations, denuclearization, China and the two Koreas

\section{Introduction}

Many astonishingly dramatic events happened in 2018 involving North Korea (DPRK, Democratic People's Republic of Korea): the leaders of the two Koreas held summits and issued joint-declarations, at Panmunjom and later in Pyongyang, greeting each other and dinning together like close friends. The rather reclusive North Korean leader Kim Jong-un traveled to China three times in 100 days to meet Xi Jinping, which, in Xi's language, rekindled the spirit of comradeship and "family-like relations" between Beijing and Pyongyang (Xinhua 2018). Topping all of that, for the first time ever, the North Korean leader met with a sitting president of the United States in Singapore in June 2018 and pledged again to denuclearize the Korean Peninsula (Liptak 2018; New York Times 2018). The image of Kim Jong-un holding hands with Donald J. Trump, smiling at and patting each other, is truly a first-class drama in international relations and public diplomacy, something just months ago would be considered impossible by many, 
if not the majority of, observers.

Theatrics and excitement aside, those events have real meanings. The main issue at stake is the all-important denuclearization of North Korea. After the Trump-Kim summit, hopes naturally rose for a peaceful resolution of the North Korean nuclear issue and also perhaps the overall Korean issue, the remaining conflict of the Cold War that was supposedly ended more than a quarter century ago. Whether those aspirations will pan out and become reality or join the many dashed hopes littering the arduous road to peace in Northeast Asia still remains to be seen as of the fall of 2018. The latest developments, however, already tend to indicate dimmer prospects for a peaceful and speedy solution.

This article is an attempt to interpret, analyze, and speculate about the prospects of denuclearization of North Korea. More specifically, it attempts to analyze why and how China is facilitating or fettering that cause. Trying to go beyond the daily occurrences and dazzling words and images, I will mainly focus on the key and stable motivational factors behind Chinese action and policy. This way, hopefully, the China factor in the whole jigsaw puzzle will become clearer and uncluttered. For Beijing, a clear hierarchy of policy preferences exists as follows: the political interest of the ruling Chinese Communist Party (CCP) to stay in power forever (a goal that is as distasteful as it is threatening to the West), often at the expense of China's national interest that requires the forging of good relations with the West especially the United States; the subsequent Chinese policy of resisting, reducing, and replacing the U.S. power in East Asia; to keep the Korean status quo; and, finally, then perhaps denuclearization of the Korean Peninsula.

\section{The China Dream and Beijing's Stance}

With the world's largest population and foreign currency reserve and the second largest economy and military budget, the People's Republic of China (PRC) is now consequentially advocating a grand "China Dream" that openly calls for a rejuvenation of China's past power and glory (CCP Central Document Studies Bureau 2013; Wan 2013). While the prospects of China's rise and its future actions are both still profoundly uncertain, the PRC state is becoming ever more wealthy, powerful, and active, with an ambitious foreign policy typically befitting a rising regional superpower with global aspirations (Lampton 2008; Kissinger 2011; Sutter 2012; Mearsheimer 2014). As indicated by several important developments, China is increasingly willing and able on the world stage, promising more Chinese demands-China's new "international security activism" (Ratner et al. 2015). Few other countries feel rising Chinese power more acutely than China's immediate neighbors in Northeast Asia, a region that has historically shaped today's China and is currently crucial to China's security and economy 
(Smith 2015). However, China (and its treaty ally North Korea) has accumulated a significant "deficit of trust" in the region according to Chinese analysts (Shen 2014). Some have speculated that, in the long run especially, China's imperialist tradition in the region is likely to re-manifest itself (Y. Wang 2010). Some have already observed that Beijing is pursuing its own version of the Monroe Doctrine in the Western Pacific (Walt 2012). In profound ways, how China deals with its neighboring nations shows well the intent and style of its rising power.

On the ground, China now directly encounters and mightily struggles with the powerfully confining East Asian security structure that was born during the Cold War many decades ago. The treaty alliances that anchor this structure deeply involve the "outsider" of the United States, the main ideological and political adversary of the CCP in Beijing. Eternally worrying about regime survival, the PRC has thus pursued a top foreign policy objective of resisting and reducing the presence and influence of the United States in its neighborhood, even at the expenses of China's national and people's interest. A manifestation of this has been China's policy toward North Korea and especially the North Korean nuclear bomb-it has become a litmus test of the nature and limitation of Chinese power for the world to see. Beijing's failure so far, reflecting its unwillingness more than its inability, to stop Pyongyang's nuclear ambition has epitomized an irony that, with its ever-rising power, China's national security environment and freedom of action in East Asia are both stagnant, if not deteriorating. Left alone, the North Korean bomb undercuts China's power and prestige everyday as it poisons China-South Korea (ROK, Republic of Korea) and undermines the Chinese leadership in the region and beyond, with more and graver uncertainties and chain reactions.

To apply its substantial but likely one-shot power to force a denuclearization of the DPRK, China would risk losing its only treaty ally and ideological comrade and thus strengthen the hand of the United States-a dreadful blow to the CCP regime. The catch-22 predicament Beijing faces in dealing with nuclear North Korea, therefore, illustrates the politicized, suboptimal nature of PRC foreign policy, which may serve the CCP regime well but at the heavy expense of China's national interest. With the coded declaration of its projective of peace and stability in Northeast Asia, Beijing oscillates between pushing Pyongyang to denuclearize and accommodating, even rewarding, Pyongyang in opposition to the United States. Right after the public announcement about the June 2018 summit between Trump and Kim but before it actually took place, the somewhat dumfounded Chinese government evidently started to swing away from pressing the North Koreans. Since June 2018, U.S.-China conflicts over trade, tensions in the South China Sea, and, perhaps, also issues regarding Taiwan have all seemed to intensify, and Beijing has moved back to its traditional policy of resisting and reducing U.S. influence first and pursuing denuclearization in the DPRK second, if ever. The high hopes generated by the Trump-Kim summit may subside further 
should the current warming trends continue between Beijing and Pyongyang.

\section{Three Alliances in East Asia and China's Three-Rs Strategy}

Like other powers, China is not pursuing its foreign policy in a vacuum with total freedom. The development and action of the many partners, rivals, and especially neighbors critically define and shape Chinese foreign policy. The long-lasting Cold War era power structure in East Asia remains both the given environment that confines the PRC and the natural target for the increasingly revisionist projection of Chinese power. Three alliances still constitute the bulk of East Asian international relations: the U.S.-ROK alliance, the U.S.-Japan alliance, and the PRC-DPRK alliance. ${ }^{1}$ Furthermore, Chinese foreign policy is peculiarly driven by two sets of interests that sometimes overlap but are often in serious conflict and competition: the national interest of China as a sovereign and growing "normal" unit of the Westphalian international system and the political interest of the CCP regime as an autocratic and ideologically lonely government. To be sure, all states make and implement their foreign policies with the imprint of the regimes' wishes and desires, and regime security is often part of national interests. But the foreign policy of the nondemocratic one-party regime of the CCP is particularly and rigidly politicized to promote regime survival and security first and foremost. The gap, even divorce, between China's national interests and the CCP's political interests therefore have been profound and consistent. ${ }^{2}$ The anchoring rivalry and animosity between Beijing and Washington/Tokyo stem mostly from the pursuit of CCP's political interest instead of China's national interest, as the latter does not justify the kind of fanned hostility with the United States or Japan.

A rising power such as China "naturally" develops revisionist demands. For any revisionist foreign policy objectives to successfully serve and promote Chinese national interests in the region and beyond, China must reckon with the three alliances and may or may not seek to alter them in significant ways. The United States, the main force behind the restraining East Asian security structure, is also the chief ideological and political adversary to the CCP in Beijing. While the U.S.-anchored East Asian security framework may be somewhat inconvenient but not necessarily obstructing-much less detrimental-to China's national security and economic prosperity, the U.S. presence and leadership embodied through this framework always represents a sharp contrast, a stark challenge, and an implied mortal threat to the CCP-PRC political system. China's rise, which is heavily shadowed and tilted by the CCP's political interest, therefore, is naturally inclined to be in direct conflict with the United States, especially its presence in East Asia.

Structurally, rising Chinese power is thus shaped and confined in East Asia by the complex relationship between the PRC and the United States, the world's 
two largest and closely-linked economies that have drastically different and fundamentally competing political systems. Various speculations are already abundant about the future of that relationship, ranging from the so-called Beijing-Washington G-2 idea or a "Chinamerica" new world order, to a new Chinese rule of the world, to a fierce geopolitical struggle between the United States and the PRC first in the Western Pacific, to a coming realization of the decades-old prophecies of global clashes between the Western and the Eastern civilizations (Huntington 1996; Ferguson 2009; Jacques 2009; Friedberg 2011). ${ }^{3}$ In East Asia, however, the linchpin of the consequential PRC-U.S. relationship is the Korean Peninsula, on which the three alliances are still facing each other, and where Beijing and Washington now share some rare common interests, while confronting profound differences and conflicts.

Contrary to some of the conventional wisdom and despite the notoriously arcane and opaque nature of Chinese politics, Beijing's basic strategy toward the United States is in fact rather unambiguous: essentially, China eyes the top position of global power and leadership currently occupied by the United States with a great amount of complex feelings of antipathy, dread, and envy. The deeply rooted ideational path and the historical logic of Chinese polity determine that, without a sea change of sociopolitical institutions and values at home, the PRC is destined to be a lasting rival of and challenger to the United States, and Beijing is trying everything to resist, reduce, and replace American power and leadership so as to reorder first the neighborhood and then wherever and whenever else possible, even if doing so directly opposes China's national interest (F. Wang 2012, 2015, 2017). As one senior U.S. official commented in 2015, China and the United States are in "different beds with different dreams."

To China's neighbors and the world at large, Beijing's "three Rs" strategy of resisting, reducing, and replacing is likely to constrain significantly international cooperation (Foot and Walter 2010). It will increasingly force the nations of the world, especially in Asia, to choose sides voluntarily or involuntarily and to settle past scores and current and future issues with growing deference to Chinese demands and preferences. This three Rs strategy is deeply rooted in the peculiar Chinese traditional and ideational foundation for the making of Chinese foreign policy. It is also necessitated by the current Chinese politics: the rising PRC needs to counter American power so as to safeguard Beijing's core interest of political survival and regime security (F. Wang 2005). ${ }^{5}$

\section{China Faces North Korea and Its Bombs}

Fundamentally conditioned by the China-U.S. relationship from the very beginning, Chinese foreign policy toward the Korean Peninsula in general and toward North Korea (and its nuclear program) in particular has been complex 
and dynamic, yet understandable. With a history filled with discord, dispute, and conflict since the early days of the Korean War, North Korea has not been a reliable ally for the PRC, let alone a true friend (Shen 2013). As earlier works have demonstrated, Beijing has continuously pursued a highly pragmatic, even schizophrenically realist policy since the 1990s to gain economic benefits and earn external peace while sticking to its clear objective of dealing with the United States for political interests (F. Wang 1996, 1997, 1999, 2009). Barring any major changes in the China-U.S. relationship and any fundamental changes inside the PRC, Beijing is expected to prefer the continued survival of the DPRK regime for its political and strategic needs while developing ever-closer relations with the Republic of Korea (ROK) for important economic interests and considerations of cultivating a counterweight to Japan and the United States. Nominally supporting Korean unification, the PRC seeks to maintain the political status quo and realize denuclearization of the Korean Peninsula, precisely in that order (Bae et al. 2014; Liu, Wang, and Cui 2014).

In the spring of 2016, PRC leader Xi Jinping reaffirmed that for his Chinese Dream and Asian Dream, "China would absolutely not allow chaos on the Korean Peninsula" (Xi 2016). However, the uncertainties and conflicts of China-U.S. relations and China-Japan discord have developed further to profoundly affect and reshape China's strategic calculation about the Korean Peninsula. Beijing already appears to have accepted a nuclear North Korea. It may also be willing to entertain a Seoul-dominated united Korea if - and its indeed a big if-it is certain that a united Korea would be firmly on Beijing's side in the growing China-U.S. rivalry in the region. ${ }^{6}$ Overall, looking through various lenses, PRC analysts today seem to have complex and somewhat diverse views about North Korea, especially as a nuclear state, but largely still carefully tread the CCP party line rather than China's national interests (Freeman 2015). The new anger and loud displeasure displayed by Beijing in the aftermath of Pyongyang's defiant test of a "hydrogen bomb" in January 2016 and a ballistic missile in March of 2016 have prompted Beijing to support more United Nations (UN) Security Council sanctions against North Korea but have not moved China any closer to abandoning the DPRK regime. ${ }^{7}$ After the North Koreans defiantly tested more ballistic missiles in the spring and summer of 2016, Beijing still seemed to refuse to do the "outsourced" work of the United States in compelling Pyongyang, limiting their response to yet more angry statements (Huanqiu shibao 2016).

The same policy continued after North Korea's fifth nuclear test on September 9, 2016. In mid-2017, however, Beijing showed more cooperation with the UN sanctions against Pyongyang's new provocations, likely hoping to head off possible use of American military force by a still unpredictable new president in the White House. But, as soon as the dramatic Tump-Kim summit was announced, Beijing moved openly closer to Pyongyang to regain its balance: $\mathrm{Xi}$ not only met with Kim repeatedly but also has apparently resumed even 
increased material support to the DPRK.

The PRC has been rewarded for its pragmatic Korea policies with great strategic maneuverability in its interaction with the United States over how to address the provocative moves of the DPRK; considerable international prestige for Beijing's hosting of the multilateral talks about Korean issues, however unfruitful those talks may have been so far; and enormous economic benefits through its deepening and booming trade and investment deals with South Korea to form a great East Asian chain of production that has enabled China's lucrative exports to the United States. Beijing's acrobatic, multidimensional Korea policy, while certainly designed to serve China's own interests (especially the CCP's political interests), has indeed contributed to the maintenance of the status quo on the Korean Peninsula, including the division of the Peninsula and the North Korean nuclear program.

Beijing's recognition of the ROK in 1992 and its rapidly expanding friendship and business ties with South Korea ever since, as well as its policy of quietly opposing Korean unification, have had their backlashes, though. Necessarily squeezed and naturally feeling shortchanged and even let down by their Chinese comrades, the DPRK embarked in the mid-1990s on a daring road to provocatively yet cleverly acquire nuclear weapons to bolster its regime security and bargaining position. North Korean nuclearization has threatened to break the international regime of the Treaty on the Non-Proliferation of Nuclear Weapons (NPT), destabilized Northeast Asia by causing uncertainties about Japanese and ROK reactions, and alarmed and agitated the United States. It has inevitably weakened and harmed the power and national interests of the PRC, which is still the only "legitimate" nuclear power in East Asia, and put both the Chinese reputation of a peaceful rise and the Sino-DPRK alliance to test. In addition to its nuclear ambition, the DPRK has also engaged in numerous actions of provocation, such as testing ballistic missiles and shelling South Korea, to make noisy demands. All of those are arguably rational for the security and survival of Pyongyang's dynastic regime, but none of them appear to be well-coordinated with PRC foreign policy, let alone serving Beijing's national strategic interests in the region, even threatening to undermine CCP's political interests as well.

In response, Beijing has addressed the development and seized upon the opportunity to cultivate a rare but real common strategic interest with the United States on denuclearization of the Korean Peninsula to strengthen its hand in relations with Washington, especially in the difficult years prior to the 9/11 attacks in 2001. Since then, the distracted United States further allowed and assisted the Chinese in recouping and extracting more prestige by gracing the many rounds of the Beijing-hosted Six-Party Talks, involving the two Koreas, China, Japan, Russia, and the United States (Bajoria and Xu 2013; Arms Control Association 2018). North Korea's desperate and daring defiance has thus provided a major stage for the Chinese government to score multilateral diplomacy 
points, earn international responsibility and leadership credits, and manage its relationship with the United States (Snyder 2013; Munroe and Blanchard 2015). Nevertheless, despite great fanfare and high hopes, those talks have largely come up empty handed and now are practically defunct because China has refused to truly pressure Pyongyang to give up its bomb.

The politically valuable accomplishment of diplomacy in Northeast Asia notwithstanding, China as a nation has endured significant costs for the CCP: the PRC has been providing massive economic aid to sustain the failed North Korean economy, "even as it tightens sanctions on North Korean nuclear programs" (Reilly 2014). The largely one-way flow of Chinese resources and, lately, the growing commercial deals have had only limited economic returns with even less diplomatic gains for China, sometimes not even so much as sincere appreciation from Pyongyang. ${ }^{8}$ With its new bomb, North Korea has become less of an inferior partner in the PRC-DPRK alliance and acquired significantly more bargaining, even extortion-like, power over Beijing, as some PRC analysts have now openly acknowledged. ${ }^{9}$ Kim's summits with Trump and ROK President Moon Jae-in in 2018 further elevated his position.

More important, perhaps, China's national interests and even national security have in fact suffered despite the rise of Chinese economic and military might: China has now become the only country in the world with four nuclear powers at its border, and DPRK-initiated nuclear proliferation would further undermine China's power position and freedom of action in East Asia if the North Korean nuclear program sets off a chain reaction leading to an arms race, even a nuclear arms race, in the region. For Beijing, a nuclear Japan appears to be one of the biggest nightmares and perhaps the worst outcome of the DPRK bomb. Worse still, China only has the goodwill of the United States to rely on to prevent that from happening. ${ }^{10}$ For all that, it is natural to see that China has been increasingly open in words and actions about its deep frustration with nuclear North Korea after 2012 when Xi Jinping took over in Beijing (Choo 2013). But the political line of the three-Rs strategy against the United States remains clear and strong in guiding Chinese policy, even after Pyongyang's highly irritating acts in 2016 and 2017 (Francis 2017). The Sino-North Korean "rekindling" in 2018 just well-illustrated that point, and demonstrated, once again, the low quality of Chinese diplomacy due to the fact that the CCP's political interest has hijacked China's national interest.

\section{The China Dilemma: Between the North Korean Bomb and the United States}

For many years, the Chinese view about the North Korean bomb has been fundamentally dictated by the CCP's political interests and objectives. ${ }^{11}$ In 
practice, Beijing is therefore seen wobbling with its ambivalent policy for stability of the status quo and also for denuclearization. The shadow of the three-Rs strategy is long and dark ( $\mathrm{Gu} 2012)$. As some PRC analysts have openly argued, the North Korean bomb may indeed be "violating China's wish and interests... but it is a price [that] must be paid for China to support [North] Korea to oppose and check the United States," since the security threat possessed by the North Korean bomb "is much larger to the United States than to China" (Zhou 2010). Furthermore, the existence of the DPRK, even nuclear armed, continues to provide a strategic buffer between China and the United States and provides, more importantly, a "useful bargaining chip in the Sino-American game" as Washington "needs Chinese cooperation more" if Pyongyang continues to cause more trouble (ibid.). Even though not many Chinese analysts have openly embraced the nuclear-stability logic advocated by Kenneth Waltz (2012) in the case of Iran, many Chinese do not object to the notion that nuclear weapons in the hands of "good people" are not inherently evil. So, the Chinese policy toward nuclear North Korea is just "how to control and manage" this strategic asset, rather than getting rid of it, let alone at a heavy cost to the CCP/PRC: risking the loss of the only treaty ally it has (Zhou 2010). Increasingly discussed behind closed doors by those worrying that China might actually be the first and real victim of the DPRK bomb or a North Korean nuclear disaster, however, this mainstream view remains intact, as the Chinese official media insists cynically that the Chinese would not be the "first victims" of the Pyongyang bomb anyway (Huanqiu shibao 2016).

Grudgingly, Beijing has grown to "swallow the bitter fruit" and tacitly accept nuclear North Korea despite its genuine wish and open rhetoric against the DPRK nuclear program, which could enhance the U.S.-Japan alliance and even lead to nuclearization of the whole of East Asia. ${ }^{12}$ As a fellow authoritarian regime that went through frightening international isolation and gambled its own security and survival on developing nuclear weapons, the CCP/PRC seems to have a hard time logically dissuading its North Korean comrades from following suit. As the only treaty ally that serves as a useful strategic buffer or asset and a rare ideological companion (the only after the U.S.-Cuba rapprochement), North Korea's existence itself is of considerable value to the PRC, especially to the CCP rulers in the eternal fight to resist and reduce U.S. power. However, unlike most other patron-client relationships, the PRC-DPRK relationship has always featured a defiant Pyongyang and a maladroit Beijing. The repeated brutal purges of the DPRK top leadership by its ruler, such as the dramatic execution of Jang Song-taek in December 2013, have effectively limited, even rooted out, Chinese influence in Pyongyang (Rauhala 2013). ${ }^{13}$ It is often not the dog that wags the tail but the other way around in the PRC-DPRK alliance. ${ }^{14}$ This is indeed a powerful, yet under-examined problem-even failure-of China's over-politicized foreign policy. The dramatic events in 2018 further demonstrated Pyongyang's play of 
Beijing on the international stage.

Therefore, caught between a rock (the CCP's political interest in resisting the U.S.-Japan alliance) and a hard place (China's national interest in opposing the North Korean nuclear program), Beijing has little choice but to continue its seemingly useful policy of milking the situation for as much political gain as possible to help its rivalry with the United States and Japan, while leaving the status quo of Korean division and the North Korean bomb drifting, hoping for the best. ${ }^{15}$ This is arguably a clever albeit expedient political decision, but it incurs considerable and growing costs for China's national interests, even national security, in a rather irresponsible way. China's freedom of action is also affected, as its main geopolitical rival, the U.S.-Japan alliance, gets to make empowering moves justified by the North Korean bomb, as reflected by the historic "groundbreaking upgrade" of the alliance in April 2015 (USDOD 2015). The U.S. "pivot to Asia," renamed and expanded to be the new Indo-Pacific Priority (USDOD 2018), and efforts such as the "U.S.-Japan-ROK Trilateral Dialogue," as well as the upgrades of military technologies by the American and Japanese militaries in the Western Pacific, may indeed "put China in an ever-shrinking security box" (Zagoria 2012). The upgraded military ties among the United States, Japan, and India, exemplified by the Malabar exercises and sharing of military technology (Pandit 2014), further altered China's security environment. The decision by South Korea to finally deploy the U.S. Terminal High Altitude Area Defense (THAAD) systems, especially its X-Band radar in the summer of 2016, is just one of such negative consequences Beijing dislikes ardently (Teng 2015; Vantage Point 2015; Kang 2016). Even Russia started to offer help with the North Korean space program, undermining China's power over Pyongyang (Morrison 2015). Rising China is therefore interestingly and unfortunately confined on the Korean Peninsula by its only ally's defiant, desperate, but rational—and seemingly effective-drive for regime survival through acquisition of the bomb. In order to check the United States, Beijing is now ironically checked by its perceived and professed strategic asset.

Empirically, the PRC keeps on playing its self-anointed role of the mediator and its pretended "neutral" role of the host for peace. ${ }^{16}$ On the one hand, China increasingly shows displeasure and disapproval of the North Korean bomb by promising more pressure on defiant Pyongyang, especially after the highly infuriating North Korean tests in 2016 (Gordon 2014; Kuhn 2016). The PRC has indeed made some noticeable and potentially profound new gestures and actions: President Xi Jinping took a much-celebrated state visit to South Korea in July 2014 to toast the "special" and "traditional" Sino-Korean friendship but has largely turned a cold shoulder to North Korean leaders, changing a traditional routine of his predecessors who would visit Pyongyang before Seoul. ${ }^{17}$

China indeed has significantly more power over North Korea since it is the "largest and the dominant" foreign donor and patron (Manyin and Nikitin 2014), 
literally feeding and fueling the DPRK. Yet, without much genuine confidence about Seoul's future strategic reorientation in the China-U.S. competition as the trade-off, and also dreading the consequences of a collapsing DPRK with the bomb, Beijing seems to still have no strategic intention or political will to really apply its potentially decisive but likely one-shot pressure to seriously cripple North Korea into submission on the nuclear issue. Like what happened to another former ally, Albania, in the 1970s and 1980s, Beijing's seemingly powerful leverage may well, once applied, have only a one-shot effect and then quickly force its beneficiary to run to the enemy's camp (that of the United States) and become an open nemesis at lightning speed (Liu 2015). Indeed, in the spring of 2016, some in Beijing already circulated a supposed Japanese report based on an alleged DPRK "internal document" showing that Kim Jong-un "now hates China more than the U.S. and South Korea" and issued orders to "resist Chinese repression policies" (Yue 2016). Enhancing rather than reducing American power in Northeast Asia, though it may not negatively impact China's national interest, is categorically unacceptable to the CCP. Once again, the CCP's political needs and calculus dictate Chinese foreign policy. Perhaps also, Beijing seems to know what some American analysts have concluded: "North Korea was never serious about giving up a nuclear program...that it saw as vital to regime protection and internal legitimacy" (Terry and Boot 2015). By mid-2018, Beijing seems to be genuinely alarmed by Pyongyang's possible "defection" to the United States thus reversed much of its gestures and actions of pressuring the North Koreans in the previous few years.

On the other hand, the negative consequences brought by the North Korean bomb on Chinese national interests and national security are now growing and have started to concern the Chinese foreign policy community and the increasingly nationalistic Chinese elites at large. It appeared to have then started to affect the CCP's political calculation centered on regime survival and security. In 2013, senior Chinese official and analyst Deng Yuwen, who was the deputy editor of a major journal of the CCP's Central Party School, characterized the DPRK as the "Kim Dynasty" that is now increasingly a major liability, even a lethal danger, for China and called for Beijing to "abandon" Pyongyang in favor of denuclearization and Korean unification. ${ }^{18}$ Despite that such views are in fact widely shared inside China, however, Beijing still curbs them publicly, in this case by penalizing Deng with a paid suspension (Perlez 2013). Nevertheless, Deng (lately a member of an "unofficial" think tank in Beijing) continued to publish overseas about a pending collapse of the DPRK in ten to fifteen years (Deng 2016). Such occasionally open expression of harsh Chinese views, effective or not in influencing Pyongyang, signifies the mood in Beijing. Of course, all that "new thinking" has now appeared to come to a halt when Kim Jung-un and Donald Trump shared the spotlight. The CCP's political interest, when it feels affected, takes over rather quickly. Beijing has essentially decided, once again, to urge the 
United States, and its allies, to also accept North Korea's nuclear status and ideally share the Chinese burden of financially sustaining the DPRK so as to, hopefully, buy possible denuclearization or at least nonproliferation and continue the status quo on the Korean Peninsula (Tiezzi 2014, 2015).

To pursue the CCP's political interest and China's national interest, which are in conflict with regard to the issue of North Korean nuclear program, Beijing is visibly frustrated but continues to support Pyongyang (Ryall 2014). This is especially true since China is yet to achieve its much craved status of "Rich Country and Strong Army" so as to rid the CCP of its eternal fear of regime nonsurvival (Hu 2011). Stuck in its endless struggle to resist, reduce, and replace American power and American leadership, Beijing thus ironically allows and even finances the North Korean bomb, canceling much of the geopolitical gains made by the prosperous Chinese economy and the rapid buildup of the People's Liberation Army (PLA) in East Asia. New ideas are often simply suppressed. For example, senior government analysts in Beijing have already openly warned against people who "use the [North] Korean issue" to smuggle in and instigate "a color revolution in China" (Ren 2014). The fear of Pyongyang somehow "defecting" to the U.S. camp hangs over Beijing all the time. The CCP appears to be afraid that an honest and thoroughly nationalist reexamination of China's failed policy on the North Korean bomb and criticisms of its Pyongyang comrades may start and inflame a nationalist political movement in China to threaten the party's rule. Therefore, the CCP leadership has rationally and even craftly set a mainly expedient and reactionary policy toward the North Korean bomb, which is also clearly suboptimal to China's national interests. Its shortcomings and failures can be amply seen in China's reactions to the North Korean diplomatic successes in 2018.

\section{Conclusion}

Just like elsewhere, such as in sub-Saharan Africa where there seems to be a costly and consequential split in Chinese foreign policy between China's national/ people's interest and Beijing's political interest (Wang and Elliot 2014), on the Korean Peninsula there is also an impact on Chinese diplomacy from a divorce between China's national interest and the CCP's core mission of regime survival. Nourished by the surging calls of the PRC statist nationalism or patriotism, rising Chinese power is already seen exercising "new" leadership in East Asia as part of the overall strategic game with the United States. The CCP hopes to reduce and replace the dreaded American power in the region through acquiring deference and submission based on fear or courting to be generated by achieving power parity, even superiority, in the region versus the United States. This is further powered by the "important decision to build China into a great maritime 
power" made by the CCP leadership - an unspecified but grand new plan for the expansion of Chinese maritime presence and power (CCTV 2013). An outspoken spokesman of the PLA openly declared that the PRC must build up its military power as fast as it can so to "make foes suffer and give friends goodies" and that "only when we are not afraid of the United States anymore, other nations will then be afraid of us." 19

Unfortunately, however, China's only treaty ally has come into the middle of that grand strategy for its own political interest. Nuclear North Korea has compromised Beijing's new position of power and leadership. Between the North Korean nuclear bomb and the United States, Beijing has so far largely chosen Pyongyang, however resentfully, compromising and undermining its new power and freedom of action at the expense of China's national interests. Without a major political change in China that lessens the CCP's dictation of Chinese foreign policy or a major geopolitical shift such as a realignment in Northeast Asia, Beijing will continue to walk the tightwire of keeping nuclear North Korea safe while dealing with the United States to hopefully deter Pyongyang's further nuclear ambitions and especially prevent a chain reaction that may lead to a nuclear Japan. Total denuclearization of the DPRK now appears to be realistically a low priority for Beijing, even though Beijing still repeats its wishes for denuclearizing the Korean Peninsula peacefully. Kim Jong-un's latest diplomatic breakthroughs have, so far, become good examples of the tail wagging the dog in the PRC-DPRK relationship.

In the future, the overlap of China's national interests and the CCP's political interest with regard to the North Korean bomb may re-emerge and grow to prompt more effective Chinese efforts to preserve the NPT and denuclearization, provided that the expedient intersection of U.S. and Chinese diplomatic objectives continues, Beijing's dread over U.S. advances in the region subsides, and Pyongyang overplays its hand. A window of opportunity still exists, and may even widen, for concerted action by the United States and China to seriously control the situation and to eventually get rid of the festering nuclear issue in Northeast Asia so as to prevent a nuclear chain reaction, which would be contrary to both American and Chinese interests. Yet, in reality, Beijing's deeply harbored, politically-driven three-Rs strategy against the United States is preventing full and effective Sino-American cooperation to resolve the Korean nuclear issue. The PRC seems determined to have a win-win for itself: to prevent nuclear proliferation and a nuclear arms race in Northeast Asia while continuing to resist and reduce American power through rebalancing and enhancing its ties with Pyongyang so as to "deepen cooperation" with its ideological comrade (Guo and $\mathrm{Lu}$ 2015). Washington may also accordingly be contemplating using Pyongyang as a new leverage in dealing with the rising Chinese challenge in the region and beyond (Fingar 2017). This U.S.-China strategic rivalry, interestingly and profoundly, may end up ironically prolonging the DPRK nuclear program thus 
opposing their shared interest of denuclearizing Korean Peninsula. A small power can indeed survive and even get its way between the two competing giants.

A diminution, even dismantling, of the U.S.-ROK alliance-such as the idea proposed by some South Korean analysts "to limit the strategic flexibility of U.S. forces stationed in South Korea, the most sensitive issue to China, to the objective of maintaining peace on and stability of the Korean Peninsula" (Chung 2015) - and a new PRC-ROK united front (first in the name of "against Japan") may effectively encourage many inside the PRC to adopt a new policy toward the DPRK and persuade Beijing to get serious about the North Korean bomb and even support ROK-led Korean unification. But, just as there are significant doubts about and opposition to rapid Korean unification inside and outside of South Korea itself (Terry 2014; Delury and Moon 2014), profound questions remain about if, what, and how the South Koreans would ever be willing to pay Beijing for getting rid of the North Korean bomb. An evident chain reaction sparked by the North Korean bomb, such as serious attempts by Japan to follow suit, would also powerfully alter Beijing's rationale. Much, of course, depends still on what transpires in China-U.S. relations. ${ }^{20}$ To the Chinese, the question is not if or whether the PRC should or would abandon North Korea-it is just a matter of right price and right timing (Zhou 2010; Perlez 2014). The CCP's political interests, rather than China's national interests, are the main-even sole-criterion. A keen observer noted in 2015 that nuclear North Korea, with its concerted efforts to develop effective delivery systems such as submarinelaunched ballistic missiles, has already infringed on China's "core interests," including its political interest of regime survival and security and may thus change the game to cause Beijing to alter its failed policy toward Pyongyang ( $\mathrm{Xu}$ 2015).

It is clear that nuclear DPRK has indeed cost China in terms of its national interest and national security but has so far had a relatively light impact on the real core interest of PRC diplomacy: the political survival and power of the CCP served by the pursuit of the three-Rs strategy against the United States. If and when Beijing deems that the damages caused by the North Korean bomb to Chinese national interests and national security start to impair the CCP regime and reduce, even cancel, the payoffs from upsetting and costing the United States in the region, China may then be fully expected to deal with North Korean denuclearization more seriously and aggressively. The catch is that, by that time, it may be way too late already, and the nuclear chain reaction may have already taken place in East Asia (Jun 2016).

For Beijing, there is the danger that the North Korean nuclear issue may get out of control given the inevitable misperceptions and miscalculations that have abundantly colored the history of East Asian international relations over the past century. If push comes to shove, an externally forced denuclearization could drive a desperate regime in Pyongyang to do desperate things, with uncertain 
but likely grave consequences for China's national security, economic prosperity, and ultimately the CCP's power. ${ }^{21}$ In that sense, nuclear North Korea may have already acquired significant deterrence against and meaningful confinement of the mighty rising China, with just six nuclear tests and some rudimentary bombs and missiles (Perlez 2017). Chinese analysts have indeed acknowledged that and have started to suggest to Americans as well that they "treat the DPRK as a [legitimate] nuclear power" in any future denuclearization talks. ${ }^{22}$ Underneath the warming of the Beijing-Pyongyang traditional relationship in the aftermath of the Trump-Kim summit is the same motivational factors driving China's policy towards the Korean nuclear issue, especially the CCP's three-Rs strategy against the United States. The ongoing cross-Pacific trade war and the heating up of other Sino-American disputes such as the Taiwan issue and the tensions in the South China Sea are likely to enhance and solidify Beijing's non-cooperative policy on the Korean nuclear issue and also on Korean unification (Bradsher and Myers 2018). Beijing's ambivalent and hesitant attitude as well as empty words about the two Koreas' latest declared intention to end the Korean War, for example, are quite telling.

Alternatively facilitating and fettering, Beijing's role is sure making North Korean denuclearization unavoidably long and arduous, if doable at all. Indeed, many in the United States, including the White House, have now openly expressed the view that the peaceful denuclearization of North Korea is hindered heavily by the Sino-American sparring over a rather broad spectrum of disputes and conflicts (Trump 2018). Given what has been analyzed in this article, a fundamental change of Beijing's strategic stance on the North Korean nuclear issue to genuinely facilitate a peaceful solution is rather unforeseeable as it would require literally a political change-of-heart in Beijing. Christopher Hill, a former top U.S. diplomat deeply involved in the issue before, now observes, "the wheels have come off whatever was agreed to or understood between North Korean leader Kim Jong Un and U.S. President Donald Trump in Singapore" and, "as a consequence, a bitter irony of the U.S. initiative has been a Chinese-North Korean rapprochement of the kind that hasn't been seen in a decade" (Hill 2018). Victor Cha, another former senior U.S. diplomat on Korea, simply asserts that the North Koreans "are getting everything they want right now" mostly thanks to China's reopening of trade with the DPRK, without giving up their bombs at all (Luce and Dilanian 2018). Unwilling (or unable) to genuinely force Pyongyang to denuclearize, Beijing is more than willing and able to spoil the effort for sure.

\section{Acknowledgement}

The author thanks the two anonymous reviewers for very helpful comments and editing. 


\section{Notes}

1. The Beijing-Pyongyang military alliance is based on the PRC-DPRK Friendship, Cooperation and Mutual Assistance Treaty, first signed in 1961, automatically renewed twice, and is currently effective until 2021.

2. For how the CCP repeatedly ceded Chinese territories for its regime survival and security, see Fravel (2005). For how the Chinese foreign policy has always been shaped by the CCP's domestic political agenda, see Garver (2016).

3. For an Asian optimistic view, see Boon (2013).

4. Author's interview in Washington, May 2015.

5. Top PRC diplomats openly declare that China's main foreign policy goal is indeed to safeguard its political system. Dai Binguo quoted in Li (2009); also see Yi Wang (2013).

6. Author's interviews with Chinese officials, officers, and scholars, 2012-2014.

7. For example, Beijing reportedly lobbied Washington to lift the new sanctions so as not to really crush the North Koran economy (Nichols, Charbonneau, and Pearson 2016).

8. Author's interviews of Chinese diplomats and officials, 2012-2013. PRC citizens have also started to complain openly about this: for example, Si (2010).

9. Huanqiu shibao (2013); author's interviews with Chinese analysts, 2016.

10. Author's interviews of Chinese analysts and officials in 2010-2015.

11. For an example of mainstream Chinese views, see Li (2014); Cao (2014); and H. Wang (2015).

12. Author's interview of a Chinese senior military analyst, 2013.

13. Jang was rumored to be colluding with Beijing to plot against Kim Jong-un.

14. For an analysis of how North Korea has cleverly and effectively bargained and balanced against China in the post-Cold War era, see Pardo and Reeves (2014).

15. To a lesser extent, similar resistance to and accommodation of the hegemon by the rising powers are identified with regard to the Iranian nuclear issue (Pieper 2014).

16. Beijing has constantly tried to persuade Seoul to hold summit talks with Pyongyang to stabilize the situation, for example, as revealed by former ROK president Lee Myungbak's memoir published in early 2015 (Choe 2015).

17. North Korea Network Expert Panel (2014). Yet, Beijing dispatched Liu Yunshan, a top leader, to attend Pyongyang's big celebration for its party's seventieth birthday the next year (Fenghuang xinwen 2015).

18. Deng (2013). Several Chinese analysts the author privately interviewed in 2013 and 2014 "agreed fully" with Deng, although some thought Deng had "just jumped the gun."

19. PLA Navy major general Yang Yi quoted in Liu (2012).

20. The United States, especially Congress, seems to be developing more new suspicions about Beijing regarding the latter's NPT commitment. See Mufson (2015).

21. Chinese officials have started to openly voice this concern (Fu 2016).

22. Senior Chinese scholars and military analysts, speaking at the U.S.-China Seminar on Chinese Nuclear Perspectives, Carnegie Endowment for International Peace, Washington, May 12, 2015. 


\section{References}

Arms Control Association. 2018. "The Six-Party Talks at a Glance." Accessed October 24, 2018, https://www.armscontrol.org/factsheets/6partytalks.

Bae, Jung-Ho, Young-Ho Park, Jae-Jeok Park, Dongsoo Kim, and Jangho Kim. 2014. The Perceptions of Northeast Asia's Four States on Korean Unification. Seoul: KINU, 28-37.

Bajoria, Jayshree, and Beina Xu. 2013. "The Six-Party Talks on North Korea's Nuclear Program." CFR Backgrounders, September 30.

Boon, Hoo Tiang. 2013. "G2 or Chimerica? The Growing Institutionalisation of US-China Relations." Eurasia Review, RSIS, Nanyang Technological University, No. 137, July 23.

Bradsher, Keith, and Steven Lee Myers. 2018. “Trump's Trade War Is Rattling China's Leaders." New York Times, August 15.

Cao, Shigong. 2014. "Shi Chaoxian wei baiynalang zhe que daju guan" [Those Who Think (North) Korea Is an Ungrateful Wolf Do Not Have Macro Views]. Huanqiu shibao [Global Times], December 2.

CCP (Chinese Communist Party) Central Document Studies Bureau. 2013. Xi Jinping guangyu shixian zhonghua minzu weida fuxing de Zhongguo Meng lunshu zhaibian [Selections of Xi Jinping's Words on Realizing the China Dream for the Great Rejuvenation of the Chinese Nation]. Beijing: Zhongyang Wenxian.

CCTV. 2013. "Xi Jinping: tuidong haiyang qiangguo jianshe" [Xi Jinping: To push Forward the Construction of a Maritime Great Power]. July 31.

Choe, Sang-Hun. 2015. "North Korea Sought Talks and Attached a Hefty Price Tag, South's Ex-Leader Says." New York Times, January 30.

Choo, Jaewoo. 2013. "China's Frustration over North Korea: Editorial Analysis, Dec. 2012-April 2013." Korean Journal of Security Affairs 18 (June): 4-21.

Chung, Jae-jung. 2015. "Views on Contingency Plan of China under Xi Jinping's Leadership for Abrupt Serious Development in North Korea." Vantage Point 38 (April): 40.

Delury, John, and Chung-in Moon. 2014. "A Reunified Theory: Should We Welcome the Collapse of North Korea?" Foreign Affairs, November-December.

Deng, Yuwen. 2013. “China Should Abandon North Korea.” Financial Times, February 27.

Deng, Yuwen. 2016. "Chaoxian bengkui de kenengxing jiqi fangshi" [The Possibility and Ways of a Korean Collapse]. Lianhe zaobao [United Daily], Singapore, April 30.

Fenghuang xinwen [Phoenix News]. 2015. "Liu Yunshan fang chaoxian" [Liu Yushan Visits Korea]. October 12. http://news.ifeng.com/world/special/lysfwcx/ (accessed October 31, 2018.

Ferguson, Niall. 2009. “What 'Chimerica' Hath Wrought.” American Interest, JanuaryFebruary.

Fingar, Thomas, ed. 2017. Uneasy Partnerships: China's Engagement with Japan, the Koreas, and Russia in the Era of Reform. Stanford: Stanford University Press.

Foot, Rosemary, and Andrew Walter. 2010. China, the United States, and Global Order. New York: Cambridge University Press.

Francis, David. 2016. "Beijing Blasts New U.S. Sanctions on North Korea." Foreign Policy, March 17.

Fravel, M. Taylor. 2005. "Regime Insecurity and International Cooperation: Explaining China’s Compromises in Territorial Disputes." International Security 30 (Fall): 46-83. 
Freeman, Carla, ed. 2015. China and North Korea: Strategic and Policy Perspectives from a Changing China. New York: Palgrave Macmillan.

Friedberg, Aaron L. 2011. A Contest for Supremacy: China, America, and the Struggle for Mastery in Asia. New York: Norton.

Fu, Yin. 2016. “People's Congress Press Conference.” Xinhua, March 4.

Garver, John W. 2016. China's Quest: Foreign Relations of the People's Republic of China. New York: Oxford University Press.

Gordon, Michael R. 2014. "China Set to Press North Korea Further on Nuclear Aims, Kerry Says.” New York Times, February 15.

Gu, Guoliang. 2012. "Cooperation and Differences between China and the U.S. in Handling the North Korean Nuclear Issue." Korean Review 2 (May): 63-80.

Guo, Yina, and Rui Lu. 2015. "Chinese Ambassador to [North] Korea: China and [North] Korea Should Seize the Opportunity to Deepen Cooperation." Xinhua, May 4.

Hill, Christopher R. 2018. “The U.S. Needs a New North Korea Strategy." Foreign Affairs, September 5.

Hu, Jintao. 2011. "Meeting the PLA Delegation.” Xinhua and CCTV, March 12.

Huanqiu shibao [Global Times]. 2013. "Chaoxian yinggai jiji di zouchu zhanlue gaoya" [(North) Korea Should Actively Walk Away from the Strategic Pressure, editorial]. April 11.

Huanqiu shibao [Global Times]. 2016. "Mei buying zhiwang jiang chaohe wenti waibao gei zhongguo" [The U.S. Should Not Count on Outsourcing the Korean Nuclear Issue to China, editorial]. April 25.

Huntington, Samuel P. 1996. The Clash of Civilizations and the Remaking of World Order. New York: Simon \& Schuster.

Jacques, Martin. 2009. When China Rules the World: The End of the Western World and the Birth of a New Global Order. New York: Penguin.

Jun, Baoyan. 2016. "Zhongguo jundui jianjue baowei guojia liyi” [Chinese Military Resolutely Protects National Interests]. Jiefangjun bao [PLA Daily], July 13.

Kang, Seung-woo. 2016. “THAAD Decision Irreversible: Park.” Korean Times, August 2.

Kissinger, Henry. 2011. On China. New York: Penguin.

Kuhn, Anthony. 2016. "Why China Supports New Sanctions against North Korea." National Public Radio, March 18.

Lampton, David. 2008. The Three Faces of Chinese Power: Might, Money, and Minds. Berkeley: University of California Press.

Li, Dunqiu. 2014. "Buneng 'fangqi' Chaoxian zhe 65nian de huoban" [Cannot "Abandon" the 65-Year Partner (North) Korea]. Huanqiu shibao [Global Times], November 2.

Li, Jing. 2009. "Shoulun zhongmei jingji duihua" [First Round of Sino-American Economic Dialogue]. China News Agency, July 29.

Liptak, Kevin. 2018. “Trump's North Korean Gamble Ends with 'Special Bond' with Kim.” CNN, June 12.

Liu, Bin 2012. "Sijuji ganbu de 'shijie guan"' [Worldviews of the Bureau-Level Officials]. Nanfang zhoumu [Southern Weekend], April 27.

Liu, Ming, Cheng-zhi Wang, and Rong-wei Cui. 2014. "Chinese Perspectives on the East Asian Security Environment and the Korean Peninsula." In The Trust-Building Process and Korean Unification, ed. Jinwook Choi. Seoul: KINU.

Liu, Zhihe. 2015. “Chaoxian: xia yige Albania?” [(North) Korea: The Next Albania?]. 
21ccom.net, July 2.

Luce, Dan De, and Ken Dilanian. 2018. "China Eases Economic Pressure on North Korea, Undercutting the Trump Administration." NBC News, September 5.

Manyin, Mark E., and Mary Beth D. Nikitin. 2014. "Foreign Assistance to North Korea." Congressional Research Service, April 2.

Mearsheimer, John J. 2014. "Can China Rise Peacefully?” National Interest, October 25.

Morrison, Aaron. 2015. "Russia and North Korea Space Program." International Business Times, April 17.

Mufson, Steven. 2015. “Obama’s Quiet Nuclear Deal with China Raises Proliferation Concerns." Washington Post, May 10.

Munroe, Tony, and Ben Blanchard. 2015. "North Korea's Neighbors Push to Resume SixParty Talks." Reuters, March 26.

New York Times. 2018. "The Trump-Kim Summit Statement: Read the Full Text." June 12.

Nichols, Michelle, Louis Charbonneau, and James Pearson. 2016. "Exclusive: U.N. Lifts North Korea Sanctions on Four Ships at China’s Request." Reuters, March 22.

North Korea Network Expert Panel. 2014. "China Snubs North Korea with Leader's Visit to South Korea." Guardian, July 3.

Pandit, Rajat. 2014. "India, US and Japan to Kick Off Malabar Naval Exercise Tomorrow." Times of India, July 23.

Pardo, Ramon Pacheco, and Jeffrey Reeves. "Weak Power Bargaining with China: Mongolia and North Korea in Comparative Perspective." Journal of Contemporary China 23 (90): 1152-1173.

Perlez, Jane. 2013. “Chinese Editor Suspended for Article on North Korea." New York Times, April 2.

Perlez, Jane. 2014. "Chinese Annoyance with North Korea Bubbles to the Surface." New York Times, December 21.

Perlez, Jane. 2017. “North Korea's Nuclear Arsenal Threatens China's Path to Power." New York Times, September 6.

Pieper, Moritz. 2014. "Chinese, Russian, and Turkish Policies in the Iranian Nuclear Dossier: Between Resistance to Hegemony and Hegemonic Accommodation." Asian Journal of Peacebuilding 2 (1): 17-36.

Ratner, Ely, Elbridge Colby, Andrew Erickson, Zachary Hosford, and Alexander Sullivan. 2015. More Willing and Able: Charting China's International Security Activism. Washington D.C.: Center for a New American Security.

Rauhala, Emily. 2013. "Kim Jong-un's Purge of His Uncle May Test Ties with China." Time, December 9.

Reilly, James. 2014. “The Curious Case of China's Aid to North Korea." Asian Survey 54 (6): 1158-1183.

Ren, Weidong. 2014. "Jingti jie Chaoxian huati zuo zhongguo wenzhang” [Watch Out for Borrowing Korean Topic for Chinese Article]. Huanqiu shibao [Global Times], October 13.

Richards, Clint. 2014. "X-Band and THAAD as Good as Anti-China Trilateral Defense Agreement?" Diplomat, October 24.

Ryall, Julian. 2014. "Frustrated China Unable to Abandon North Korea." Deutsche Welle, May 22. http://www.dw.com/en/frustrated-china-unable-to-abandon-north-korea/ a-17652998 (accessed October 24, 2018). 
Shen, Dingli. 2014. "Changing Security Environment in Northeast Asia and the TrustBuilding Process on the Korean Peninsula." In The Trust-building Process and Korean Unification, ed. Jinwook Choi, 89-110. Seoul: KINU.

Shen, Zhihua. 2013. "Zhongchao guangxi jingtian neimu" [The Shocking Inside Story of Sino-Korean Relations]. September 3. http://history.sina.com.cn/his/zl/2013-0903/102952867.shtml (accessed October 24, 2018).

Si, Weijiang. 2010. "Women weishimu yao yuanzhu chaoxian" [Why do we aid Korea]. http://www.chinainperspective.com/ArtShow.aspx?AID=9076 (accessed October 31, 2018).

Smith, Sheila A. 2015. Intimate Rivals: Japanese Domestic Politics and a Rising China. New York: Columbia University Press.

Snyder, Scott A. 2013. "China's Persistent Support for the Six-Party Talks." Atlantic, September 19.

Sutter, Robert. 2012. Chinese Foreign Relations. Lanham, MD: Rowman \& Littlefield.

Teng, Jianqun. 2015. "Why Is China Unhappy with the Deployment of THAAD in the ROK?" Asan Forum, March 31. http://www.theasanforum.org/an-chineseperspective/ (accessed October 24, 2018).

Terry, Sue Mi. 2014. "A Korea Whole and Free: Why Unifying the Peninsula Won't Be So Bad after All." Foreign Affairs, July-August.

Terry, Sue Mi, and Max Boot. 2015. “The Wrong Lessons from North Korea: Avoiding a Nuclear Iran." Foreign Affairs, April 22.

Tiezzi, Shannon. 2014. "China Responds to North Korea's Nuclear Threat." Diplomat, November 21.

Tiezzi, Shannon. 2015. “China Urges US to Accept North Korea’s ‘Olive Branch.”' Diplomat, January 17.

Trump, Donald J. 2018. Twitter Post. August 24, 10:36 AM. https://twitter.com/ realDonaldTrump/status/1033045274866999297 (accessed October 24, 2018).

USDOD (United States Department of Defense). 2015. The Guidelines for U.S.-Japan Defense Cooperation. April 27.

USDOD (United States Department of Defense). 2018. The DOD Focus on the Indo-Pacific. https://dod.defense.gov/News/Special-Reports/0118_the-indo-pacific/ (accessed September 5, 2018).

Vantage Point. 2015. "China's Objection of THAAD Deployment in S. Korea." March, 1821.

Walt, Steven. 2012. "Dealing with a Chinese Monroe Doctrine." New York Times, May 3.

Waltz, Kenneth N. 2012. "Why Iran Should Get the Bomb: Nuclear Balancing Would Mean Stability." Foreign Affairs 91 (4): 2-5.

Wan, Ming. 2013. “Xi Jinping's 'China Dream': Same Bed, Different Dreams?” Asan Forum, August 2. http://www.theasanforum.org/xi-jinpings-china-dream-same-beddifferent-dreams/ (accessed October 24, 2018).

Wang, Fei-Ling. 1996. "Changing Views: Chinese Perception of the United States-South Korea Alliance." Problems of Post-Communism (July-August): 25-34.

Wang, Fei-Ling. 1997. Tacit Acceptance and Watchful Eyes: Beijing's Views about the U.S.ROK Alliance. Carlisle, PA: Strategic Studies Institute, U.S. Army War College.

Wang, Fei-Ling. 1999. “Joining the Major Powers for the Status Quo: China's Views and Policy on Korean Reunification." Pacific Affairs 72 (2): 167-185. 
Wang, Fei-Ling. 2005. "Beijing's Incentive Structure: The Pursuit of Preservation, Prosperity, and Power." In China Rising: Power and Motivation in Chinese Foreign Policy, eds. Yong Deng and Fei-Ling Wang. Lanham, MD: Rowman \& Littlefield.

Wang, Fei-Ling. 2009. "Looking East: China's Policy toward the Korean Peninsula." In Engagement with North Korea: A Viable Alternative, eds. Sung Chull Kim and David C. Kang, 47-72. Albany, NY: SUNY Press.

Wang, Fei-Ling. 2012. "Resisting, Reducing, and Replacing: China's Strategy and Policy towards the United States." In China's Domestic Politics and Foreign Policies, and Major Countries' Strategies on China, ed. Jung-Ho Bae, 155-186. Seoul: KINU.

Wang, Fei-Ling. 2015. "China's Four-R Strategy toward the United States: Resisting, Reducing, Replacing and Reordering." In Studies on China, ed. Mahendra Gaur. New Delhi: Foreign Policy Research Centre.

Wang, Fei-Ling. 2017. The China Order: Centralia, World Empire, and the Nature of Chinese Power. Albany, NY: SUNY Press.

Wang, Fei-Ling, and Esi A. Elliot. 2014. "China in Africa: Presence, Perceptions and Prospects." Journal of Contemporary China 23 (90): 1012-1032.

Wang, Hongguang. 2015. "Renhe huanhe bandao jushi de judong dou yingdang shou huanying" [Should Welcome Any Move of Détente on the Peninsula]. Huanqiu shibao [Global Times], January 27.

Wang, Yi. 2013. "Shixi xinxing quanqiuzhili tixi de goujian ji zhidu jianshe" [Analyzing the Building and Institutional Construction of a New Type of Global Governance System]. Guowai lilun dongtai [State of Foreign Theories] 8: 5-11.

Wang, Yuan-kang. 2010. Harmony and War: Confucian Culture and Chinese Power Politics. New York: Columbia University Press.

$\mathrm{Xi}$, Jinping. 2016. "Zai yaxin wuci waizhang huiyi kaimoshi shang de jianghua” (Speech at the Opening Ceremony of the Fifth CICA Foreign Ministers Meeting). Xinhua, April 28.

Xinhua. 2018. "Xi Jinping tong Jin Zhengen juxing huitan" [Xi Jinping and Kim Jung-un Held a Meeting). March 3.

$\mathrm{Xu}$, Litai. 2015. "Bei Han chufan zhongguo hexin liye" [North Korea Offends China's Core Interest], May 21. https://www.lieguozhi.com/xsyj/xsdt/246399.shtml_ (accessed October 24, 2018).

Yue, Cheng. 2016. “Jin Zhengen duihua chouheng chao meihan” [Kim Jong-un hates China More than U.S. and South Korea]. Duowei xinwen [Duowei News], March 27. http:// global.dwnews.com/news/2016-03-27/59728176.html (accessed October 24, 2018).

Zagoria, Donald S. 2012. "U.S.-Japan-ROK Trilateral Dialogue." National Committee on American Foreign Policy, May.

Zhou, Huilai. 2010. "Zhongguo fangqi chaoxian hai weishi guozao" [It's Too Early for China to Abandon North Korea]. Iianhe zaobao [United daily], June 15.

Fei-Ling Wang is a professor at the Sam Nunn School of International Affairs, Georgia Institute of Technology. His most recent book is The China Order: Centralia, World Empire, and the Nature of Chinese Power (Albany: SUNY Press, 2017). He is a member of the Council on Foreign Relations. Parts of this paper were published in "Between the Bomb and the United States: China Faces the 
Nuclear North Korea" in Sung Chull Kim and Michael Cohen eds., The North Korean Nuclear Challenge: How the bomb would influence North Korea and the region (Washington D.C.: Georgetown University Press, 2017).

Submitted: September 15, 2018; Revised: October 23, 2018; Accepted: October 24, 2018 